\title{
DISPOSISI DAN KENISCAYAAN SEBAGAI MODALITAS HUKUM ALAM
}

\author{
Martin SURYAJAYA*
}

\begin{abstract}
A debate is growing today about the ontological status of disposition in relation to the modality of natural law. This debate arose after the failure of Humean actualism to explain the basis of causality. Categoricalism tries to overcome the weaknesses of actualism by restoring the concept of disposition that is reduced to a set of categorical properties. Through such a move, categoricalism hopes to explain the basis of the disposition and yet fails to guarantee the necessity of natural law. Another alternative is to formulate a variant of dispositionalism in which dispositions are regarded as fundamental properties that are irreducible to categorical properties. Dispositionalists attempt to set up a concept of disposition which acknow-ledges the existence of unactualized disposition and guarantees the necessity of natural law. This essay, however, will demonstrate that dispositionalists' solution is not free from the similar dilemma which haunts categoricalism.
\end{abstract}

Keywords: Actuality, categorical property, dispositional property, supervenience, causality, finkish disposition, antidote, necessity.

Abstrak: Dewasa ini berkembang perdebatan tentang status ontologis disposisi dalam kaitannya dengan modalitas hukum alam. Perdebatan ini mengemuka selepas kegagalan aktualisme Humean dalam menjelaskan landasan kausalitas. Kategorialisme mencoba mengatasi kelemahan aktualisme dengan mengembalikan konsep disposisi yang direduksi pada sekumpulan sifat kategoris. Melalui langkah ini, kategorialisme berharap dapat menerangkan landasan dari disposisi, tetapi sesungguhnya gagal mengajukan suatu konsepsi tentang hukum alam yang niscaya. Alternatifnya adalah merumuskan suatu varian dari disposisionalisme di mana disposisi adalah sifat fundamental benda yang tidak tereduksikan pada sifat

* Martin Suryajaya, Program Studi Desain Komunikasi Visual, Universitas Multimedia Nusantara, Jl. Scientia Boulevard, Gading Serpong, Tangerang, Banten-15811. E-mail: martinsuryajaya@gmail.com. 
kategoris. Kaum disposisionalis berupaya membangun konsepsi tentang disposisi yang, di satu sisi, mengakui adanya disposisi yang tidak teraktualisasi dan, di sisi lain, menjamin keniscayaan hukum alam. Akan tetapi, melalui artikel ini akan ditunjukkan juga bahwa solusi disposisionalis tersebut tidak lepas dari dilema serupa yang menghantui kategorialisme.

Kata-kata Kunci: Aktualitas, sifat kategoris, sifat disposisional, kebertopangan, kausalitas, disposisi-pelenyapan, penawar, keniscayaan.

\section{PENDAHULUAN}

Mengapa gunting dapat memotong selembar kertas? Karena gunting mengandung sifat "dapat memotong benda dengan tingkat kekerasan di bawah $x$ " dan kertas memiliki sifat "mengandung tingkat kekerasan di bawah $x$." Dalam kosakata metafisika era modern, tepatnya Locke, sifat yang dimiliki gunting disebut sebagai "daya aktif" (active power) dan sifat kertas sebagai "daya pasif" (passive power). ${ }^{1}$ Daya aktif adalah kemampuan yang dimiliki suatu benda untuk mengubah benda lain, sementara daya pasif adalah kemampuan suatu benda untuk diubah atau menerima perubahan. Peristiwa kausal terpotongnya selembar kertas oleh gunting dimungkinkan karena bekerjanya daya-daya atau disposisi di muka. ${ }^{2}$ Oleh karena ilmu pengetahuan hendak menyingkapkan hubungan kausal yang bekerja dalam dunia, maka sumbangan konsep disposisi bagi ilmu-ilmu tidak dapat dipungkiri.

Artikel ini berfokus pada dua pertanyaan: apakah status ontologis disposisi $^{3}$ dan bagaimana disposisi berkaitan dengan persoalan modalitas

1 "Power, thus considered, is two-fold, viz. as able to make, or able to receive, any change: the one may be called active, and the other passive power." John Locke, The Works of John Locke Volume I: An Essay Concerning Human Understanding, Part I (London: Rivington, 1824), p. 174 .

2 Bdk. definisi yang diberikan Harré dan Madden tentang daya berikut: "X has the power to $A^{\prime}$ means 'X (will) (can) do A, in the appropriate conditions, in virtue of its intrinsic nature." Rom Harré and Edward H. Madden, Causal Powers: A Theory of Natural Necessity (Oxford: Basil Blackwell, 1975), p. 86.

3 Hal pertama yang harus dijernihkan dalam setiap pembicaraan tentang disposisi adalah persoalan hubungan antara sifat (property) dan predikat. Hal ini penting untuk dijernihkan sebab disposisi adalah suatu sifat yang dimiliki oleh benda. Semua filosof kontemporer yang terlibat dalam perdebatan tentang disposisi berangkat dari distingsi 
hukum alam, yakni tentang niscaya/kontinjennya hukum alam. Apa yang dipersoalkan dari status ontologis disposisi adalah keberadaan disposisi yang tidak teraktualisasi. Terdapat tiga skema jawaban umum dalam filsafat kontemporer tentang disposisi semacam itu: aktualisme, kategorialisme, dan disposisionalisme. Ketiga model jawaban tersebut memiliki implikasinya sendiri terhadap persoalan modalitas hukum alam. Penulis akan mendekati persoalan status ontologis disposisi dan modalitas

antara sifat dan predikat [Bdk., misalnya, pengamatan Alexander Bird dalam Nature's Metaphysics: Laws and Properties (Oxford: Clarendon Press, 2007), pp. 9-10]. Seperti dinyatakan oleh George Molnar, predikat adalah entitas yang bergantung pada bahasa, sementara sifat adalah karakter kenyataan yang dapat independen terhadap bahasa atau pikiran [George Molnar, Powers: A Study in Metaphysics, ed. Stephen Mumford (Oxford: Oxford University Press, 2006), p. 25]. Tidak ada korespondensi satu-satu antara totalitas predikat dan totalitas sifat sebab domain predikat lebih luas dari domain apa yang secara alamiah disebut sebagai sifat. Agar lebih menjernihkan persoalan, kita akan mengikuti David Lewis dengan membuat distingsi antara sifat alamiah (natural property) dan sifat non-alamiah [David Lewis, On The Plurality of Worlds (Oxford: Basil Blackwell, 1986), pp. 60-61]. Sifat alamiah adalah sifat yang mengkonstitusikan jenis alamiah (natural kind) suatu benda. Misalnya, sifat "memiliki bilangan atomik 88" atau "mengandung disposisi untuk teroksidasi dalam kontak dengan udara" merupakan sifat alamiah radium. Akan tetapi, sifat seperti "ditemukan oleh Marie Curie" atau "dipublikasikan pada 26 Desember 1898" bukanlah sifat alamiah radium. Kedua sifat terakhir itulah yang disebut sebagai sifat non-alamiah, yakni sifat yang tidak esensial bagi adanya objek yang dikenai sifat tersebut. Radium tetap ada dalam suatu dunia di mana Marie Curie tidak pernah menemukannya dan penemuan itu tidak menambah ataupun mengurangi sifat alamiahnya. Sebaliknya, radium bukanlah radium apabila ia tidak mengandung disposisi untuk teroksidasi dalam kontak dengan udara. Apa yang dinyatakan oleh predikat adalah kedua jenis sifat di muka, baik alamiah maupun non-alamiah. Dengan demikian, tidak ada korespondensi satu-satu antara totalitas predikat dan totalitas sifat dalam pengertian alamiahnya. Konsepsi tentang sifat yang digunakan oleh semua yang berpartisipasi dalam perdebatan tentang disposisi adalah konsepsi sifat alamiah. Inilah yang disebut oleh David Lewis sebagai sparse theory of property atau apa yang disebut sebagai "realisme selektif tentang sifat" oleh George Molnar [David Lewis, On The Plurality of Worlds, p. 59-60; George Molnar, Powers, p. 25]. Sebelum Lewis, David Armstrong juga sudah menunjuk pada distingsi yang serupa ketika ia membedakan antara 'predikat murni' dan 'tidak murni' (pure and impure predicate). Predikat murni adalah predikat yang mengacu pada objek universal (misalnya, "keturunan raja"), sementara predikat tidak murni adalah predikat yang mengacu pada objek partikular (misalnya, "keturunan Charlemagne"). Lih. D.M. Armstrong, Universals \& Scientific Realism Volume II: A Theory of Universals (Cambridge: Cambridge University Press, 1978), p. 15. Berdasarkan kosakata Armstrong ini, sifat "memiliki bilangan atomik 88" merupakan predikat murni, sementara sifat "ditemu-kan oleh Marie Curie" merupakan predikat tidak murni. Konsepsi sifat semacam ini lebih ekonomis ketimbang konsepsi sifat yang disamakan dengan predikat. Berdasarkan konsepsi sifat alamiah, kita cukup menerangkan sifat disposisional gunting sebagai "dapat memotong benda dengan tingkat kekerasan di bawah $x^{\prime \prime}$ ketimbang harus berbicara juga tentang sifat "dapat 
hukum alam ini dengan kerangka baca yang secara umum bersimpati pada realisme ilmiah (scientific realism). Sebagai salah satu aliran dalam filsafat ilmu, ciri utama realisme ilmiah adalah pengakuan akan keberadaan independen objek-objek yang dinyatakan oleh ilmu-ilmu terlepas dari kesadaran para ilmuwan tentangnya kendati pengetahuan akan objek tersebut harus berangkat dari laporan fenomenal. Simpati pada realisme ilmiah inilah yang menjelaskan mengapa penulis nantinya akan mendukung posisi yang lebih menjamin status ontologis disposisi dan konsepsi tentang hukum alam sebagai keniscayaan. Dalam artikel ini secara berturut-turut penulis akan mengulas posisi aktualisme, kategorialisme, dan disposisionalisme. Dalam bagian penutup penulis akan memberikan catatan kritis yang menunjukkan bahwa jawaban terbaru atas persoalan di muka, yakni disposisionalisme, ternyata juga problematis.

\section{MENGAPA AKTUALISME DITINGGALKAN?}

Dalam An Enquiry Concerning Human Understanding, David Hume menyatakan bahwa konsepsi yang kita miliki tentang daya (power) atau disposisi yang inheren dalam benda dibentuk oleh kebiasaan kita dalam mengamati seri peristiwa yang berurutan. ${ }^{4}$ Oleh karena kita terbiasa mengamati urut-urutan yang terjadi di antara dua peristiwa, kita lantas menyimpulkan bahwa terdapat daya yang inheren dalam benda pada peristiwa pertama yang menyebabkan munculnya peristiwa kedua. Hume sendiri tidak mempersoalkan keberadaan daya semacam itu; ia hanya meragukan kemungkinan bahwa kita dapat menyimpulkan keberadaannya. Dengan kata lain, ia tidak mengajukan dakuan ontologis bahwa daya

memotong kain," "dapat memotong kain berwarna hijau," "dapat memotong kain berwarna hijau bermotif polkadot" dan seterusnya.

4 "It appears, then, that this idea of a necessary connexion among events arises from a number of similar instances, which occur, of the constant conjunction of these events [...]This connexion, therefore, which we feel in the mind, this customary transition of the imagination from one object to its usual attendant, is the sentiment or impression, from which we form the idea of power or necessary connexion. Nothing farther is in the case. [...] In all single instances of the operation of bodies or minds, there is nothing that produces any impression, nor consequently can suggest any idea, of power or necessary connexion. But when many uniform instances appear, and the same object is always followed by the same event; we then begin to entertain the notion of cause and connexion." David Hume, An Enquiry Concerning Human Understanding, ed. Peter Millican (Oxford: Oxford University Press, 2007), pp. 54-57. 
inheren benda itu tidak ada, melainkan mengajukan dakuan epistemologis bahwa kita tidak dapat mengetahuinya. Namun, di tangan Humean kontemporer, argumen Hume tersebut dibawa ke taraf ontologis: daya inheren benda tidak ada. ${ }^{5}$ Apa yang ada kemudian direduksi pada apa yang terberi pada pengamat. Karena apa yang terberi adalah aktualitas empirik benda-benda, maka dunia kemudian disamakan dengan ranah aktualitas tersebut. ${ }^{6}$

Konsepsi tentang dunia yang telah direduksi ke dalam aktualisasi empiriknya bukanlah suatu konsepsi yang baru. Dalam Metafisika $\Theta$, Aristoteles mencatat pandangan para pemikir dari Megara yang menyatakan bahwa "suatu hal hanya dapat bertindak ketika ia bertindak dan ketika ia tidak bertindak ia tidak dapat bertindak, misalnya ia yang tidak membangun tidak dapat membangun."7 George Molnar menyebut pandangan ini sebagai aktualisme dan merumuskan definisi umum kaum aktualis tentang daya:

5 Salah satu Humean kontemporer, John Mackie, mengatakan bahwa "intrinsic powers are pretty clearly products of metaphysical double vision: they just are the causal process which they are supposed to explain seen over again as somehow latent in the things that enter into these processes." Dikutip dari George Molnar, Powers: A Study in Metaphysics, ed. Stephen Mumford (Oxford: Oxford University Press, 2006), p. 97.

6 Roy Bhaskar berpendapat bahwa reduksi atas dunia ke dalam aktualisasi empiriknya merupakan konsekuensi tidak langsung dari empirisisme Humean sendiri. Begitu konsepsi positif apapun tentang dunia eksternal ditunda, netralitas dunia eksternal itu sendiri dengan mudah dianggap sebagai beban yang tidak ekonomis untuk dipertahankan dan diam-diam digantikan dengan konsepsi empirisis tentang dunia. "Humean empiricism is not neutral in its consequences for scientific practice. Taken consistently, it does generate a methodology; not indeed Hume's (or Newton's), but Mach's. For in the absence of the concept of an ontological realm, the implicit realism generated implies that whatever is experienced in sense-experience is an event and whatever constant conjunctions are experienced are causal laws. In this way, our current knowledge fills the vacuuum left by the dissolution of the ontological realm; and in so doing it squeezes out, metaphorically speaking, the possibility of any substantive scientific criticism. In the methodology of Humean empiricism facts, which are social products, usurp the place of the particulars of the world; and their conjunctions, which are doubly social products, the place of causal laws." Roy Bhaskar, A Realist Theory of Science (Leeds: Leeds Books, 1975), p. 42.

7 "There are some who say, as the Megaric school does, that a thing can act only when it is acting, and when it is not acting it cannot act, e.g. he who is not building cannot build, but only he who is building, when he is building; and so in all other cases." Metaphysics 1046b29-32. 
$\mathbf{D}_{1}$ : Pada waktu $w$, objek $x$ memiliki daya untuk $f$ jika dan hanya jika $x$ mewujudkan daya untuk $f$ pada $w .^{8}$

Berdasarkan definisi di muka terlihat bahwa, bagi kaum aktualis, tidak mungkin ada daya yang tidak teraktualisasikan. Daya hanya ada manakala ada manifestasinya. Hume sendiri, dalam A Treatise of Human Nature, menyatakan hal yang serupa: "Distingsi yang terkadang dibuat antara sebuah daya dan keberlakuan-nya sepenuhnya tidak berguna dan tidak seorang atau suatu hal pun yang mesti dianggap memiliki kemampuan kecuali kemampuan itu diberlakukan dan diwujudkan dalam tindakan." 9 Pandangan ini memiliki konsekuensi yang tidak masuk akal.

Aristoteles menunjukkan dua persoalan yang tidak terjawab oleh para aktualis dari Megara. Pertama, bagaimana menjelaskan fakta bahwa orang dapat kembali mengaktualisasikan suatu keahlian setelah ia berhenti menggunakannya (Met. 1046b34-1047a3)? Apabila kemampuan membangun hanya ada ketika kemampuan itu diaktualisasikan, maka setiap kali tukang bangunan berhenti membangun seketika itu juga ia kehilangan kemampuannya untuk membangun. Jika demikian, kita tidak akan bisa menjelaskan perubahan dari kondisi tidak memiliki kemampuan ke kondisi memiliki kemampuan - kita tidak mampu menerangkan perubahan apapun. Kedua, bagaimana menjelaskan perbedaan antara orang buta dan orang yang memejamkan matanya (Met. 1047a5-10)? Kalau kemampuan melihat hanya ada ketika ada tindak melihat, maka orang yang memejamkan matanya sama saja dengan orang buta. Artinya, tidak ada perbedaan antara daya yang tidak teraktualisasikan dan ketiadaan daya sama sekali. ${ }^{10}$ Di samping itu, terdapat persoalan ketiga yang tidak terjawab oleh kaum aktualis, yakni soal jaminan atas keniscayaan hukum

8 George Molnar, Powers: A Study in Metaphysics, ed. Stephen Mumford (Oxford: Oxford University Press, 2006), p. 95.

9 "It has been observed, in treating of the the understanding, that the distinction which we sometimes make betwixt a power and the exercise of it, is entirely frivolous, and that neither man nor any other being ought ever to be thought possessed of any ability, unless it be exerted and put in action." David Hume, The Philosophical Works Volume II: A Treatise of Human Nature, Part II and III (Edinburgh: Adam Black and William Tait, 1826), p. 46.

10 Bdk. George Molnar, Powers, p. 97. 
alam. Oleh karena segala sesuatunya ada sejauh teraktualisasi, landasan bagi kausalitas jadi tidak terpikirkan sehingga dakuan tentang hukum hanya mungkin dialaskan pada aktualisasi suksesif fenomena yang ajeg. Persoalan-persoalan tidak terjawab inilah yang mendorong para filosof untuk menjadi seorang realis berkenaan dengan daya atau disposisi. Daya benda atau kemampuannya untuk berlaku secara tertentu adalah sifat objektif benda dan bukan sekadar hasil asosiasi antarkesan indrawi. ${ }^{11}$

Berbagai teori realis tentang disposisi memiliki ragam dimensi yang tidak mungkin dikupas seluruhnya dalam artikel ini. Oleh karena itu, di sini penulis hanya akan menguraikan salah satu tema dalam perdebatan tentang disposisi, yakni mengenai status ontologis disposisi dan implikasinya terhadap modalitas hukum alam.

\section{KATEGORIALISME DAN KONTINJENSI HUKUM ALAM}

Pembicaraan tentang status ontologis disposisi mesti diawali dengan distingsi antara "sifat disposisional" (dispositional property) dan "sifat kategoris" (categorical property). Mengikuti contoh kita di awal artikel ini, sifat gunting "dapat memotong benda dengan tingkat kekerasan di bawah $x$ " merupakan contoh sifat disposisional, sementara sifat kertas "memiliki tingkat kekerasan di bawah $x^{\prime \prime}$ adalah contoh sifat kategoris. Sifat disposisional adalah sifat benda yang mengarah pada aktualisasi tertentu, sementara sifat kategoris adalah sifat benda yang non-disposisional, yang ditentukan berdasarkan "ke-apa-an"-nya (quidditas). Apa yang dipersoalkan dalam perdebatan kontemporer tentang disposisi adalah hubungan antara kedua jenis sifat di muka.

Dalam kerangka "kategorialisme" (categorialism) yang antara lain dirumuskan oleh David Armstrong, semua sifat pada dasarnya merupakan sifat kategoris. ${ }^{12}$ Dikatakan "pada dasarnya" karena posisi ini masih me-

11 Aristoteles sendiri menunjukkan bahwa konsepsi aktualis tentang daya berisiko membawa kita pada relativisme sofistik. "[S]imilarly with regard to lifeless things; nothing will either be cold or hot or sweet or perceptible at all if people are not perceiving it; so that the upholders of this view will have to maintain the doctrine of Protagoras [homo mensura - penulis]." Metaphysics 1047a4-6.

12 "All true properties [...] are non-dispositional. [...] Properties are self-contained things, keeping 
ngakui keberadaan disposisi dalam kenyataan objektif. Apa yang tidak diakuinya adalah status ontologis yang fundamental dari disposisi. Tentu saja, pertanyaan tentang "apa yang ada" mesti dibedakan dari pertanyaan tentang "apa yang ada secara fundamental." Menurut posisi ini, sifat disposisional adalah sifat derivatif yang diturunkan dari sifat kategoris. Untuk menjelaskan status derivatif sifat disposisional kita memerlukan konsep supervenience yang secara tentatif akan penulis terjemahkan sebagai "kebertopangan."13

Relasi kebertopangan dapat dinyatakan secara ekstensional ${ }^{14}$ sebagai berikut. David Chalmers mengatakan bahwa sifat B bertopang pada sifat A jika dan hanya jika tidak ada dua situasi yang mungkin yang identik dalam hal sifat A tetapi tidak identik dalam hal sifat B. ${ }^{15}$ Armstrong memberikan definisi yang serupa: “Q bertopang pada $P$ jika dan hanya jika terdapat dunia-dunia P dan semua dunia P adalah dunia Q."16 Dirumus-

themselves to themselves, not pointing beyond themselves to further effects brought about in virtue of such properties." David Armstrong, A World of States of Affairs (Cambridge: Cambridge University Press, 1997), p. 80.

13 Menurut Brian P. McLaughlin, kata kerja supervene dibentuk dari kata Latin super yang artinya "di atas" atau "tambahan" dan venire atau "datang" sehingga kata supervene dalam bahasa Inggris sehari-hari diartikan sebagai "datang sebagai tambahan" atau "hadir sebagai sesuatu yang tidak diduga-duga." Lih. Brian P. McLaughlin, "Varieties of Supervenience" in Supervenience: New Essays, eds. Elias E. Savellos dan Ümit D. Yalçin (Cambridge: Cambridge University Press, 1995), p. 16. Oleh karena itu, pengertian sehari-hari atas kata supervenience berbeda dengan pengertian teknisnya. Adapun demikian, akar kata supervene dalam bahasa Yunani lebih dekat dengan pengertian teknisnya kini. Menurut Peter Geach, kata supervenient dalam bahasa Inggris didapat melalui terjemahan Robert Grosseteste, seorang filosof Abad Pertengahan, atas potongan teks Etika Nikomakhea Aristoteles (1174b31-3). Dalam teks tersebut, kata epiginomenon diterjemahkan oleh Grosseteste sebagai supervenire. Mengenai ini, lih. Brian P. McLaughlin, "Emergence and Supervenience" in Emergence: Contemporary Readings in Philosophy and Science, eds. Mark A. Bedau dan Paul Humphreys (Massachusetts: The MIT Press, 2008), p. 96.

14 "Keluasan" (extension) dari sebuah ungkapan adalah domain objek-objek yang diacu dengan ungkapan tersebut. Lih. Harry Deutsch, "Extension/intension" dalam A Companion to Metaphysics, eds. Jaegwon Kim (West Sussex: Wiley-Blackwell, 2009), p. 254. Frase "secara ekstensional" yang digunakan dalam artikel ini mengacu ke pengertian modal-nya, yakni luas domain objek dalam totalitas dunia yang mungkin. Pengertian keluasan semacam ini lazimnya digunakan untuk mengukur kuat/ lemahnya suatu dakuan tentang keniscayaan, sebagaimana akan kita lihat nanti.

15 David Chalmers, "Supervenience" in Emergence, eds. Mark A. Bedau and Paul Humphreys, p. 412.

16 David Armstrong, A World of States of Affairs, p. 11. 
kan secara berbeda, B bertopang pada A jika dan hanya jika tidak ada perubahan pada B tanpa perubahan pada A. Dalam hal ini, A dapat dikatakan sebagai "basis penopang" (supervenience base) dari B dan B sebagai "sifat yang bertopang" (supervening property). ${ }^{17}$ Dalam ranah philosophy of mind, misalnya, dikatakan bahwa rasa sakit bertopang pada rangsangan fiber-C karena tidak mungkin ada rasa sakit tanpa adanya rangsangan fiber-C pada susunan syaraf otak. ${ }^{18}$

Berdasarkan konsep kebertopangan inilah Armstrong merumuskan hubungan antara sifat kategoris dan sifat disposisional. Sifat disposisional disebut derivatif karena sifat tersebut bertopang pada sifat kategoris. Bayangkan sebuah bola karet yang dapat memantul apabila dibenturkan ke dinding. Apa yang membuat sifat disposisional "mudah terpantul" berciri disposisional sebagaimana adanya? Menurut kategorialis seperti Armstrong, adanya sifat kategoris "memiliki tingkat elastisitas $y$ " memungkinkan bola karet tersebut mengandung disposisi "mudah terpantul" ketika terbentur dinding dengan sifat kategoris tertentu. Atau mengambil contoh dari Armstrong sendiri, sifat disposisional "mudah pecah" ditentukan oleh sifat kategoris seperti tingkat kerapatan molekul yang menyusun objek terkait. ${ }^{19}$ Dengan demikian, sifat disposisional benda merupakan fungsi dari struktur kategorisnya.

Melalui ilustrasi di muka, dapat kita lihat bahwa apa yang dimaksud sebagai sifat kategoris sebetulnya tidak lain adalah apa yang dalam kosakata sains modern disebut sebagai "kualitas primer" (primary quality). Kualitas primer adalah sifat benda fisik yang keberadaannya tidak

17 Bdk. Sydney Shoemaker, Physical Realization (Oxford: Oxford University Press, 2007), p. 2.

18 "An identity theorist holds that it is a good bet that research on the brain will lead to the discovery that certain properties we now designate using mental terms are properties of brains. Pain, for instance, might turn out to be the firing of $C$-fibers in the brain. (This, the standard example, has been empirically discredited, but it will do to illus-trate the point.) If this is so, then the property of being in pain would be identified with the neurological property of being a C-fiber firing." John Heil, Philosophy of Mind: A Contemporary Introduction (London: Routledge, 2004), p. 80. Para teoretisi identitas yang disebut Heil memang tidak menggunakan argumen supervenience. Para penerusnya lah yang kemudian menggunakan konsep tersebut untuk membicarakan hubungan antara sifat mental dan sifat material (misalnya antara akal budi dan otak).

19 David Armstrong, A World of States of Affairs, p. 81. 
mengandaikan hubungan sama sekali dengan pengamat. Galileo, sebagai pemikir modern pertama yang merumuskan konsep tersebut, menyebut ada empat kualitas primer: ukuran, bentuk, kuantitas, dan gerak. ${ }^{20}$ Teori tentang kualitas primer ini diadopsi juga oleh Isaac Newton dan kemudian menjadi tulang punggung korpuskularianisme (corpuscularianism). ${ }^{21}$ Korpuskularianisme adalah pandangan bahwa seluruh benda fisik tersusun oleh partikel dan keseluruhan interaksi makro antarbenda dapat dijelaskan berdasarkan hubungan antarkualitas-kualitas primer yang dikandung dalam partikel benda-benda tersebut. ${ }^{22}$ Jika demikian, kategorialisme Armstrong dapat dimengerti juga sebagai "teori korpuskularian tentang disposisi" atau pandangan bahwa disposisi suatu benda sepenuhnya terjelaskan oleh struktur kategorisnya (kualitas-kualitas primernya).

Konsekuensi dari hubungan di muka adalah bahwa sifat disposisional bukanlah sifat fundamental yang menyusun kenyataan fisik. Status sifat disposisional inilah yang disebut Armstrong sebagai "makan siang ontologis gratis" (ontological free lunch). ${ }^{23}$ Apa yang bertopang bukanlah suatu tambahan terhadap basis penopangnya. Tidak ada hal baru yang dapat dikatakan berkenaan dengan sifat yang bertopang yang tidak sudah dapat ditemukan di dalam basis penopangnya. Oleh karena sifat disposisional tidak menambahkan hal yang baru secara ontologis terhadap sifat kategoris, sifat disposisional tersebut tidak lain merupakan "makan siang ontologis gratis." Implikasinya, demi penjelasan yang lebih ekonomis, pernyataan tentang sifat disposisional dapat dan harus diparafrasekan (direduksi) ke dalam pernyataan tentang sifat kategoris. Dengan kata lain, sifat disposisional

20 "I do not believe that in order to stimulate in us tastes, odors, and sounds, external bodies require anything other than sizes, shapes, quantity, and slow or fast motions." Galileo Galilei, "The Assayer" in The Essential Galileo, ed. Maurice A. Finocchiaro (Indianapolis: Hackett Publishing Company, 2008), p. 187 (\$7.2).

21 Lih. Isaac Newton, "De Gravitatione" in Philosophical Writings, ed. Andrew Janiak (Cambridge: Cambridge University Press, 2004), p. 13 dan Isaac Newton, "Philosophiae Naturalis Principia Mathematica" in Philosophical Writings, p. 50.

22 Bdk. Rom Harré, The Philosophies of Science: An Introductory Survey (Oxford: Oxford University Press, 1985), p. 128.

23 David Armstrong, A World of States of Affairs, pp. 12-13. 
tidak memiliki status ontologis yang fundamental dan juga tidak ekonomis sebagai kerangka penjelasan.

Pengertian disposisi berdasarkan kerangka kategorialisme dapat dirumuskan sebagai berikut:

$\mathbf{D}_{2}$ : pada waktu $w$, objek $x$ memiliki daya untuk $f$ jika dan hanya jika terdapat himpunan sifat kategoris $K$ demikian rupa sehingga adanya daya untuk $f$ bertopang pada adanya himpunan $K$ pada $w$.

Dari definisi ini dapat kita lihat adanya kemiripan dengan $\mathbf{D}_{1}$. Apabila sifat disposisional bukanlah sifat fundamental yang dimiliki oleh benda dan satu-satunya jenis sifat yang dimiliki oleh benda secara fundamental adalah sifat kategoris, maka sebetulnya pandangan ini tidak sungguh berbeda dari aktualisme Humean.

Alasan dari kemiripan di muka sederhana: benda-benda, dalam kerangka kategorialis, tidak niscaya mengandung disposisi. Kepemilikan benda atas sifat-sifat disposisional adalah fakta kontinjen yang bergantung pada sifat-sifat kategoris yang menyusunnya. Kendati dalam dunia kita gunting memiliki disposisi "dapat memotong benda dengan tingkat kekerasan di bawah $x$," kita dapat membayangkan suatu dunia $d$ di mana gunting mengandung sifat kategoris "memiliki tingkat kekerasan $x-n$ " yang mengimplikasikan bahwa gunting itu tidak memiliki disposisi yang sama dengan gunting dari dunia kita. Karena itu, adanya disposisi ditentukan oleh aktualitas sifat kategorisnya atau, dengan kata lain, oleh fakta kontinjen bahwa sifat kategoris tersebut ada dalam dunia aktual (dan tidak di seluruh dunia yang mungkin). Dengan begitu, penjelasan tentang disposisi yang tidak teraktualisasikan akan direduksi pada penjelasan tentang ketiadaan sifat kategoris yang secara aktual menopang disposisi dan ini berarti-karena sifat disposisional bertopang pada sifat kategoris - ketiadaan disposisi itu sendiri. ${ }^{24}$ Permasalahan ini mempunyai

24 Armstrong sendiri mengakui bahwa pendekatannya terhadap daya yang tidak termanifestasikan bergerak dalam kerangka "pengempesan" (deflationary). "We do have to embrace a somewhat deflationary doctrine of unmanifested powers and dispositions. [...] The Megarian philosophers of old were Eliminativists about unrealized possibilities. The view now to be advocated 
implikasi yang tidak sederhana berkenaan dengan modalitas hukum alam. Apabila kepemilikan sifat kategoris oleh benda-benda merupakan fakta kontinjen, hukum alam mau tidak mau harus dipandang bersifat kontinjen pula.

Pandangan Armstrong tentang hukum harus berangkat dari identifikasi antara sifat kategoris dan universalia (universals), yakni sifat yang pengenaannya pada benda partikular dapat diulang (repeatable) tanpa berubah identitasnya. Hukum alam, baginya, adalah hubungan di antara sifat-sifat kategoris sebagai universalia. Mengikuti contoh dari Armstrong, hubungan kausal adalah jatuhnya pisau guillotine ke leher tahanan sehingga tahanan tersebut terpenggal. ${ }^{25}$ Relasi kausal ini dapat dirumuskan sebagai F $a \mathrm{RG} b \rightarrow \mathrm{H} b$. Huruf $a$ dan $b$ berturut-turut menandai "alat guillotine" dan "tahanan." Huruf-huruf kapital F, R, G dan H dalam Fa, $\mathrm{R}, \mathrm{G} b$ dan $\mathrm{H} b$ secara berturut-turut menandai sifat universal. $\mathrm{F} a$ : "sifat kategoris" dari $a$ atau "guillotine;" R: "relasi" (antara Fa dan Gb); Gb: "sifat kategoris" dari $b$ atau "tahanan;" Hb: "sifat kategoris" dari "tahanan" setelah pisau guillotine jatuh. Apa yang digambarkan di sini adalah peristiwa kausal biasa. Lantas apakah yang harus ditambahkan agar kita memperoleh hukum?

Menurut Armstrong, agar kita memperoleh hukum, kita harus mengabstraksikan semua acuan partikular dalam rumusan di atas: menghilangkan acuan pada $a$ dan $b$. Apa yang kita peroleh adalah FRG $\rightarrow \mathrm{H}$. Dalam rumusan terakhir, kita mendapatkan tautan kausal antara dua situasi (FRG, di satu sisi, dan H, di sisi lain) pada level tipe universal (type) dan bukan sekadar antarsituasi pada level tipe partikular (token). ${ }^{26}$ Armstrong sengaja tidak menggunakan "pembilang universal" (universal quantifier $)$ terhadap partikularia $a$ dan $b$ : ia tidak menulis $(\nabla a)(\nabla b)(\mathrm{F} a \mathrm{RG} b$

is to a degree Megarian in spirit. But it is an eirenic Megarianism." David Armstrong, A World of States of Affairs, p. 81.

25 Lih. David Armstrong, A World of States of Affairs, pp. 224-225.

26 "The hypothesis is that there can be causal connections not merely between state-of-affairs tokens but also between state-of-affairs types. Something's being an F and having $R$ to a further thing $G$, just that state-of-affairs type, brings about, causes, the further thing to become an $H, a$ further state-of-affairs type." David Armstrong, A World of States of Affairs, pp. 225-226. 
$\rightarrow \mathrm{Hb}$ ). Alasannya ialah bahwa, seperti dinyatakannya sendiri, menggunakan pembilang universal berarti berbicara pada aras partikular, kasus per kasus, dan hal ini berisiko jatuh pada konsepsi Humean yang mereduksi kausalitas pada suksesi reguler antarperistiwa partikular sehingga apa yang kita peroleh hanyalah "semua orang yang dijatuhi pisau guillotine terpenggal" dan bukan "penjatuhan pisau guillotine menyebabkan orang terpenggal." 27 Oleh karena hukum adalah relasi antaruniversalia, keajegan (regularity) pada ranah fenomenal dijelaskan tanpa harus mereduksi hubungan kausal pada keajegan antarperistiwa partikular itu sendiri. ${ }^{28}$ Bagi Armstrong, hukum dibentuk dari relasi (yang dinotasikan dengan “ $\rightarrow$ ") antartipe situasi yang tersusun oleh universalia; dengan kata lain, relasi antarsifat kategoris. Relasi macam apakah itu?

Relasi tersebut disebut Armstrong sebagai "peniscayaan nomik" (nomic necessitation). Relasi itu memastikan bahwa F yang berelasi secara R dengan $\mathrm{G}$ akan menyebabkan $\mathrm{H}$. Jenis relasi ini adalah relasi "tatanan kedua" (second-order relation) sebab relata dari relasi ini bukanlah benda partikular, melainkan universalia. Dengan demikian, apa yang dimaksud Armstrong dengan hukum dapat didefinisikan sebagai relasi peniscayaan nomik (tatanan-kedua) antaruniversalia. ${ }^{29}$ Berkenaan dengan relasi inilah konsepsi

27 "The universal quantification ... does not by itself entail, though it may well suggest, the hypothesized causal connection between the state-of-affairs types. [...] [G]uillotining causes immediate decapitation. This entails that all who are guillotined, are immediately without a head. But that all who are guillotined are immediately without a head does not entail that guillotining causes immediate decapitation." David Armstrong, A World of States of Affairs, p. 226.

28 "It is easy to see then that if the connection holds at the level of universals, then, automatically, the regularity is entailed. [...]The connection of properties that are universals expresses itself, without exhausting itself, in a corresponding regularity. Just as a state of affairs of a's being $F$ entails the existence of $a$ and $F$, without being exhausted by the existence of the constituents, so the postulated higher-order connection of universals entails the existence of regularities (which may be statistical only, or conditional upon the absence of extra interfering factors, etc), but is not exhausted by the regularities." David Armstrong, "Place's and Armstrong's Views Compared and Contrasted" in Dispositions: A Debate, ed. Tim Crane (London: Routledge, 1996), p. 47.

29 Bdk. penjelasan Bird tentang konsepsi Armstrong tentang hukum: "Matters of particular facts are composed of particulars (individual things) possessing universals (natural properties, including relations). Facts may also be composed of universals themselves possessing or being related by higher-order universals. Laws are facts of this higher type. The law that Fs are Gs is a matter of universals $F$ and $G$ being related by a specific second-order relation, that of nomic necessitation. The idea of nomic necessitation is that when two universals are related by it, then the presence of the first brings about the presence of the second. Thus, laws do explain 
Armstrong tentang hukum menyimpan kontradiksi yang akan membawanya ke sepasang alternatif disjungtif: atau hukum alam bersifat kontinjen dan Armstrong niscaya jatuh dalam aktualisme, atau ketaktereduksian sifat disposisional mesti direhabilitasi sehingga keniscayaan hukum dijamin. Berikut ini penulis akan mengikuti penyelidikan Alexander Bird atas kontradiksi tersebut. ${ }^{30}$

Mengatakan bahwa FRG "meniscayakan" H berarti mengatakan bahwa di seluruh dunia yang mungkin FRG menyebabkan H. Persoalannya, Armstrong tidak menganut realisme modalitas sehingga ia menolak mendefinisikan keniscayaan secara ekstensional atau, dengan kata lain, dalam kerangka "dunia-dunia yang mungkin" (possible worlds). ${ }^{31}$ Oleh karena itu, Armstrong mesti menempatkan relasi "peniscayaan nomik"nya dalam konteks dunia aktual. Jadi peniscayaan yang ia maksudkan di sini tidak dapat dimengerti dalam artinya yang kuat: tidak niscaya di seluruh dunia yang mungkin, tetapi niscaya dalam dunia sejauh sifatsifat kategoris tertentu ada. Artinya, hukum bersifat kontinjen: tergantung pada aktualitas sifat-sifat kategoris yang ada di dunia. Akan tetapi, begitu ia menempatkan relasi "peniscayaan nomik" tersebut di dunia aktual semata, persoalan segera muncul: bagaimana dengan kasus di mana FRG ada tetapi $\mathrm{H}$ tidak termanifestasikan? Di sini persoalan status ontologis disposisi yang tidak teraktualisasikan kembali menghantui Armstrong. Menurut Bird, seorang realis modalitas seperti David Lewis, akan dengan mudah menjawab pertanyaan itu dengan menyatakan "disposisi yang tidak teraktualisasikan pada dunia aktual, teraktualisasikan pada dunia lain yang mungkin," sementara Armstrong tidak dapat menjawab seperti itu. ${ }^{32}$ Dengan kata lain, di sini Armstrong dihadapkan pada dua pilihan.

their instances and the existence of regularities in the world." Alexander Bird, Nature's Metaphysics, p. 2.

30 Khususnya Alexander Bird, Nature's Metaphysics, pp. 91-97 \& 109-110.

31 "It is to be emphasized again that necessary truth is not to be defined 'extensionally', as truth in all possible worlds. It is, it would seem, a necessary truth that an object that is a kilo in mass has proper parts that are a pound in mass. The truthmaker for this truth is not to be found in any world but this." David Armstrong, A World of States of Affairs, p. 174.

32 Lih. Alexander Bird, Nature's Metaphysics, pp. 109-110. 
Pilihan pertama, ia dapat menyatakan bahwa hukum alam bersifat kontinjen karena hukum itu - relasi "peniscayaan nomik" - bertopang pada sifat-sifat kategoris yang dapat berbeda pada situasi lain. Hukum alam tidak niscaya sebab keberadaan relata dalam pernyataan hukum tersebut, yakni sifat-sifat kategoris (F, R, G, H), bersifat kontinjen (dalam arti, world-bound). Apabila ini yang ia pilih, maka ia dapat menyelamatkan program kategorialismenya (reduksi sifat disposisional pada sifat kategoris yang aktual), tetapi dengan bayaran terjatuh dalam aktualisme Humean yang menyatakan bahwa disposisi hanya ada ketika teraktualisasikan. Pilihan kedua, ia mengakui adanya disposisi yang tidak termanifestasikan dengan mendasarkannya pada ketidaktereduksian sifat disposisional terhadap sifat kategoris. Dengan begitu, sifat disposisional dapat dijadikan landasan yang menjamin keniscayaan hukum alam. Berhadapan dengan per-simpangan ini, Armstrong sendiri mengambil pilihan pertama dengan konsekuensi bahwa status hukum bersifat kontinjen dan kategorialismenya jadi nyaris tidak terbedakan dari aktualisme Humean.

\section{DISPOSISIONALISME SEBAGAI ALTERNATIF}

Dengan mereduksi sifat disposisional ke sifat kategoris, Armstrong berisiko terjatuh kembali pada aktualisme Humean dan hukum alam hanya berstatus kontinjen. Secara umum, terdapat dua alternatif terhadapnya: pan-disposisionalisme dan disposisionalisme moderat. ${ }^{33}$ Pan-disposisionalisme atau monisme disposisional adalah pandangan bahwa seluruh sifat yang dimiliki benda pada dasarnya merupakan sifat disposisional. Pandangan ini antara lain mengemuka dalam pemikiran Sydney Shoemaker awal, Alexander Bird, dan Stephen Mumford. Disposisionalisme moderat atau dualisme disposisional adalah pandangan bahwa seluruh sifat benda

33 Terdapat posisi yang agak sulit ditempatkan ke dalam salah satu dari kedua alternatif di muka. E.J. Lowe, misalnya, menolak distingsi sifat kategoris dan sifat disposisional yang didasarkan pada perbedaan di antara sifat-sifat objek. Ia cenderung memposisikan distingsi tersebut dalam kerangka distingsi antara modus keberadaan dan jenis substansi. Dalam kerangka yang dibuat oleh Lawe, predikasi sifat-sifat kategoris berkenaan dengan modus keberadaan, sementara predikasi sifat-sifat disposisional berkenaan dengan penggolongan objek ke dalam jenis substansial tertentu. Lih. E.J. Lowe, The Four-Category Ontology: A Metaphysical Foundation for Natural Science (Oxford: Clarendon Press, 2006), p. 125 
terbagi ke dalam sifat disposisional, dan sifat kategoris. Konsepsi ini terdapat dalam pemikiran Brian Ellis dan George Molnar.

Menurut pan-disposisionalis seperti Sydney Shoemaker dalam artikelnya Causality and Properties (1980), "sifat-sifat adalah kumpulan daya kondisional." ${ }^{34}$ Dalam pengertian ini, seluruh sifat adalah daya atau disposisi. Bahkan sifat yang lazimnya dianggap sifat kategoris seperti bentuk oleh kaum pan-disposisionalis dianggap sebagai sifat disposisional. Mengikuti ilustrasi Shoemaker dan Mumford, sebilah pisau mengandung disposisi untuk memotong karena hal itu berbentuk pisau. Bentuk pisau dengan begitu merupakan sifat disposisional. Artinya, apabila bentuk pisau itu diwujudkan oleh awan di langit, maka awan juga akan memiliki disposisi untuk memotong sesuatu yang memiliki tingkat kekerasan di bawahnya. ${ }^{35}$ Kendati begitu, manifestasi daya selalu bersifat kondisional. Manifestasi suatu daya mengandaikan relasinya dengan daya lain, baik yang dimiliki oleh satu objek yang sama ataupun dimiliki oleh objek lain yang berkaitan dengannya. Aktualisasi dari sifat disposisional "bentuk pisau" dalam memotong bergantung pula pada ada/tidaknya sifat disposisional "memiliki tingkat kekerasan $x$ " benda tersebut (yang memadai bagi aktualisasi daya tersebut pada objek tertentu). Demikian pula, sifat geometris seperti "melingkar" (spherical), apabila ditubuhkan pada benda fisik, mengandung disposisi untuk menggelinding pada lereng dengan sudut $45^{\circ}$. Begitu juga dengan seluruh sifat lain di semesta.

Konsepsi pan-disposisionalis ini menuai sanggahan dari Armstrong. Apa akibatnya jika segala sifat adalah sifat disposisional? Apa konsekuensi dari pernyataan - antara lain dari Mumford ${ }^{36}$ - bahwa daya bersifat sui generis? Demikian Armstrong mempersoalkan:

34 Dikutip dari Stephen Mumford, "Powers, dispositions, properties or a causal realist manifesto" in Revitalizing Causality: Realism about Causality in Philosophy and Social Science, ed. Ruth Groff (London: Routledge, 2008), p. 141.

35 "I find it preferable to say that all instances of the same property involve the same power and what is conditional is that the power be manifested. Hence, a cloud does have the power to cut but its manifestation is conditional on there being something softer than itself to cut." Stepen Mumford, "Powers, dispositions, properties or a causal realist manifesto," p. 143.

36 Mumford mengatakan bahwa daya tercipta tidak dari sifat kategoris, melainkan dari interaksi antardaya itu sendiri sehingga daya bersifat polygenic, yakni memiliki asal- 
Almarhum profesor A. Boyce Gibson dari Universitas Melbourne pernah secara menggelitik berkata bahwa para filosof bahasa selalu berkemaskemas demi sebuah perjalanan yang tidak pernah mereka tempuh. Berkenaan dengan pengertian yang murni disposisionalis tentang sifatsifat, partikularia nampaknya selalu berkemas-kemas, berubah sifatsifatnya, tetapi tidak pernah melalui perjalanan dari potensi ke aktus. Sebab "aktus," dalam pandangan ini, tidak lebih dari suatu potensi yang lain. ${ }^{37}$

Apabila setiap sifat adalah sifat disposisional, maka aktualisasi dari sebuah sifat tidak lain dari pada munculnya disposisi lain. Lebih lanjut lagi, oleh karena setiap disposisi adalah disposisi untuk sesuatu, akibatnya identitas setiap disposisi pasti relasional. Ini diakui oleh pan-disposisionalis seperti Mumford..$^{38}$ Identitas disposisi A ditentukan oleh relasinya dengan disposisi B, C, D, ..., yang berelasi dengannya. Mumford menyimpulkan bahwa apabila A hilang, maka B, C, D, ..., mesti hilang juga, demikian pula dengan semua sifat yang berelasi dengan masing-masing $\mathrm{B}, \mathrm{C}, \mathrm{D}, \ldots$, dan seterusnya.$^{39}$ Regresi ini tentunya membuat kita sulit berbicara tentang disposisi secara akurat. ${ }^{40}$

usul jamak. Mengenai ini, lih. Stephen Mumford, "Passing Powers Around," The Monist 92/1 (January, 2009), khususnya pp. 102-105.

37 David Armstrong, A World of States of Affairs, p. 80.

38 Lih. Stephen Mumford, "Powers, dispositions, properties or a causal realist manifesto," p. 148.

39 Mirip dengan sanggahan Armstrong, terdapat pula sanggahan dari Simon Blackburn: "According to Blackburn, if all intrinsic properties are powers, as pan-dispositionalism implies, then physical objects have counter-factual essences. That means that truthmakers for all truths about actual objects will be found only at neighbouring possible worlds, and because the regress holds in any world, the truths about our nearest neighbour world would in turn depend on what is true in its neigbour, etc., leading to the melancholy conclusion 'there is no truth anywhere'." George Molnar, Powers, p. 177.

40 Versi epistemologis dari regresi ini dikenal dalam literatur sebagai ‘Regresi Swinburne’ (dari artikel Richard Swinburne pada tahun 1983). Brian Ellis meringkaskan argumen Swinburne demikian: "All manifestations of powers are ultimately changes in the properties or relations of things. If such changes were just changes in the power of things, then we could know about them only if they were manifested. But we could know about these manifestations only if they in turn were manifested, and so on to an infinite regress." Brian Ellis, Scientific Essentialism (Cambridge: Cambridge University Press, 2001), p. 136. 
Posisi disposisionalisme moderat atau dualisme disposisional sepertinya terhindar dari kesulitan di muka. Bagi disposisionalis moderat, seperti Brian Ellis, terdapat sifat-sifat kategoris maupun disposisional, dan sifat-sifat disposisional tidak dapat direduksi pada sifat-sifat kategoris. Alasannya karena sifat-sifat kategoris tersebut hanya menjadi faktor kausal dan pada dirinya bukanlah daya kausal, tidak seperti sifat disposisional. Ellis memberikan ilustrasi: sifat kategoris "terpisah satu meter" tidaklah pada dirinya disposisional, tetapi sifat itu berkontribusi sebagai faktor yang relevan dalam aktualisasi disposisi seperti gaya gravitasi demikian rupa sehingga dua benda yang "terpisah satu meter" memiliki intensitas gravitasional yang lebih tinggi dari pada dua benda yang "terpisah dua meter." ${ }^{41}$ Kendati demikian, sedekat apapun kedua benda itu, tidak akan terjadi gerak tarik-menarik di antara keduanya apabila tidak ada daya kausalnya, yakni disposisi benda untuk bergravitasi. Artinya, sifat disposisional tidak dapat direduksi ke sifat kategoris karena yang pertama adalah daya kausal sementara yang kedua hanyalah faktor kausal.

Perbedaan lain antara sifat disposisional dan sifat kategoris, menurut Ellis, adalah bahwa sementara sifat disposisional bersifat esensial, sifat kategoris tidak. Mengambil contoh sederhana, secangkir kopi tidak mungkin tidak mengandung disposisi "menahan kantuk," tetapi apakah secangkir kopi tersebut berada di atas meja atau di atas permukaan lantai tentu tidak mengubah esensinya. Secangkir kopi menjadi secangkir kopi bukan karena ia berada di atas meja atau di atas lantai, melainkan karena ia mengandung disposisi "menahan kantuk." Dinyatakan secara lain, sifat disposisional suatu benda adalah sifat esensial dalam arti niscaya dimiliki benda tersebut di seluruh dunia yang mungkin di mana benda itu ada. ${ }^{42}$ Air

41 "The relation of being separated by one meter is not a causal power or propensity, although it may be a relevant factor concering the actions of such properties. Things separated by one meter may be more attracted to each other gravitationally, or more strongly repelled electrically, than similar things separated by two meters. However, it is one thing to be a relevant causal factor, because it is involved essentially in a causal relationship; it is another to be a causal power." Brian Ellis, Scientific Essentialism, p. 137.

42 Jelas nampak di sini bahwa kaum disposisionalis dipengaruhi oleh terobosan semantik Saul Kripke pada 1970 tentang status niscaya dari setiap nama-diri (proper name) yang tidak tergantikan oleh deskripsi. Kata "Nixon" menandai orang yang sama di seluruh dunia yang mungkin di mana orang itu ada. Tetapi deskripsi "orang yang meme- 
tidak mungkin tidak $\mathrm{H}_{2} \mathrm{O}$ dan karenanya tidak mungkin tidak memiliki disposisi tertentu, tetapi di dunia $w_{1}$ air mungkin banyak berada di bulan, sementara di dunia $w_{2}$ air mungkin banyak berada di planet bumi. ${ }^{43}$

Posisi disposisionalisme moderat sepertinya lebih kuat berhadapan dengan sanggahan kategorialis. Namun, sebagaimana pan-disposisionalisme, posisi ini juga berhadapan dengan masalah yang tidak sederhana ketika hendak mendefinisikan disposisi. Setiap varian dari disposisionalisme mesti dapat menjelaskan disposisi yang tidak teraktualisasi agar bebas dari risiko kategorialisme, yakni risiko terjatuh ke dalam salah satu varian aktualisme. Berikut penulis akan mengikuti uraian Alexander Bird tentang kesulitan kaum disposisionalis dalam mendefinisikan disposisi. ${ }^{44}$

Kita akan menjalankan "analisis kondisional" (conditional analysis) atas disposisi sebagaimana diuraikan oleh Bird. Andaikan "benda $x$ yang mengandung disposisi $\mathrm{D}$ untuk memanifestasikan $\mathrm{M}$ dalam respon terhadap stimulus $S$ " dinotasikan dengan " $\mathrm{D}_{(\mathrm{S}, \mathrm{M})} x^{\prime \prime}$ dan kondisional subjungtif atau kontrafaktual (maksudnya, "seandainya ..., maka ...") dinotasikan sebagai “ $\square \rightarrow$ " sehingga "S $x \square \rightarrow \mathrm{M} x$ ” dapat dibaca sebagai "seandainya $x$ dikenai $\mathrm{S}$, maka $x$ akan menjadi M." Dengan ini kita memperoleh "Analisis Kondisional" dasar atas disposisi.

$(\mathrm{AK}) \quad \mathrm{D}_{(\mathrm{S}, \mathrm{M})} x \leftrightarrow(\mathrm{S} x \square \rightarrow \mathrm{M} x)$

nangkan pemilu presiden Amerika Serikat" tidak demikian. Jadi pernyataan identitas 'Nixon adalah orang yang memenangkan pemilu presiden Amerika Serikat' tidak berstatus niscaya; pernyataan itu hanya benar di seluruh dunia yang mungkin di mana Nixon ada dan ia memenangkan pemilu presiden Amerika Serikat. Lih. Saul Kripke, Naming and Necessity (Cambridge, MA: Harvard University Press, 2001), p. 41. Persoalannya, sementara Kripke menggunakan model keniscayaan untuk kasus pernyataan identitas dan jenis alamiah (air adalah $\mathrm{H}_{2} \mathrm{O}$ ), kaum disposisionalis menariknya untuk membicarakan keniscayaan sifat disposisional. Tegangan antara disposisi dan keniscayaan lebih sulit diselesaikan ketimbang tegangan antara identitas dan keniscayaan. Kita akan lihat nanti bahwa konsepsi keniscayaan kaum disposisionalis ternyata tidak sekuat apa yang menjadi role-model-nya, yakni konsepsi Kripke.

43 "The relations of spatial separation, for example, are independent of the natures of things separated (once it is settled what are to count as their locations). Therefore, these same relations could exist in a world that is very different from ours." Brian Ellis, Scientific Essentialism, p. 138.

44 Khususnya Alexander Bird, Nature's Metaphysics, pp. 24-29 \& 36-38. 
Artinya, " $x$ memiliki disposisi D untuk manifestasikan M dalam respon stimulus $\mathrm{S}$ jika dan hanya jika seandainya $x$ dikenai $\mathrm{S}$, maka $x$ akan menjadi M." Notasi “ $\leftrightarrow$ " adalah lambang untuk hubungan bikondisional “三” yang dapat dibaca sebagai "jika dan hanya jika" (iff). Artinya, tidak mungkin $\mathrm{D}_{(\mathrm{S}, \mathrm{M})} x$ tetapi ( $\mathrm{S} x \square \rightarrow \mathrm{M} x$ ), demikian pula sebaliknya. Konsekuensinya, kedua konsepsi kondisional atas disposisi berikut mesti samasama benarnya:

$$
\begin{aligned}
& \left(\mathrm{AK}^{\mathrm{a}}\right) \mathrm{D}_{(\mathrm{S}, \mathrm{M})} x \rightarrow(\mathrm{S} x \square \rightarrow \mathrm{M} x) \\
& \left(\mathrm{AK}^{\mathrm{b}}\right)(\mathrm{S} x \square \rightarrow \mathrm{M} x) \rightarrow \mathrm{D}_{(\mathrm{S}, \mathrm{M})} x
\end{aligned}
$$

Kedua konsepsi inilah yang dipermasalahkan dalam perdebatan tentang disposisi belakangan ini. Melalui perdebatan itu mengemuka bahwa analisis kondisional standar atas disposisi (AK) ternyata tidak memadai.

Ketakmemadaian AK antara lain disebabkan oleh adanya jenis disposisi tertentu yang membatalkan manifestasi M. Bird menguraikan kedua jenis utamanya, yakni "disposisi-melenyap" (finkish disposition) dan disposisi “penawar." Disposisi-melenyap dirumuskan oleh Charlie Martin dalam salah satu artikelnya pada 1994. Suatu disposisi disebut disposisimelenyap apabila disposisi tersebut lenyap pada suatu waktu antara sesudah terjadinya stimulus dan sebelum terjadinya manifestasi. ${ }^{45}$ Ada dua persyaratan bekerjanya disposisi ini yang dipenuhi oleh setiap atau sebagian besar disposisi. Persyaratan pertama adalah bahwa proses manifestasi suatu disposisi memakan waktu demikian rupa sehingga setelah $\mathrm{S} x$ tidak seketika juga ada $\mathrm{M} x$, walaupun $\mathrm{D}_{(\mathrm{S}, \mathrm{M})} x$ dinyatakan berlaku. Persyaratan kedua adalah bahwa disposisi dapat diperoleh dan dapat hilang. Bird memberi contoh: makanan kemasan dapat terinfeksi oleh bakteri Clostridium botulinum dan karenanya memperoleh disposisi "beracun," tetapi disposisi ini dapat lenyap apabila makanan tersebut menjalani proses iradiasi (misalnya dimasak).

45 "Finkish dispositions arise because the time delay between stimulus and manifestation provides an opportnity for the disposition to go out of existence and so halt the process that would bring about the manifestation. More precisely an object's disposition is finkish when the object loses the disposition after the occurence of the stimulus but before the manifestation can occur and in such a way that consequently that manifestation does not occur." Alexander Bird, Nature's Metaphysics, p. 25. 
Bagaimana disposisi-melenyap bekerja? David Lewis memberikan contoh sebagaimana dikutip dalam karya Alexander Bird. ${ }^{46}$ Misalnya, seorang penyihir melindungi sepotong kaca yang rapuh dengan sihir yang akan aktif setiap kali kaca tersebut dipukul. Begitu kaca itu dipukul, sihir itu akan menghilangkan disposisi "rapuh" (fragile) pada kaca tersebut. Jadi, pada waktu kaca itu dipukul, kaca itu rapuh sehingga mestinya ia pecah. Tetapi, sebelum pecah, aktiflah sihir yang menghilangkan disposisi "rapuh" sehingga kaca tidak pecah. Dalam kasus ini, $\mathrm{D}_{(\mathrm{S}, \mathrm{M})} x \rightarrow(\mathrm{S} x \square \rightarrow$ $\mathrm{M} x$ ) keliru sebab adanya disposisi "rapuh" pada $x$ tidak meniscayakan $x$ pecah (tidak mengemukakan $M$ ) ketika dikenai $S$, persis karena disposisi "rapuh" itu menjadi "melenyap" lewat intervensi disposisi lain (sihir, dalam contoh di muka). Sekarang kita gunakan contoh lain dari Bird yang tidak menggunakan skenario fantastis seperti sihir. Andaikan sebuah gelas kaca yang memiliki disposisi "rapuh" terjatuh, suhu gelas tersebut meningkat drastis sehingga menghasilkan peningkatan kohesi molekul (dengan kata lain, kehilangan disposisi "rapuh") dan karenanya ia tidak pecah. Jadi, walaupun gelas itu memiliki disposisi "rapuh" pada momen ketika dipukul, tetapi karena kerapuhan menjadi "melenyap" akibat bekerjanya disposisi lain (sebut saja, disposisi "kohesi molekuler" atau sifat kategoris "kohesi molekuler" bagi disposisionalis moderat) yang menghilangkan disposisi "rapuh," maka manifestasinya tidak mengemuka. Dengan kata lain, $\mathrm{AK}^{\mathrm{a}}$ keliru.

Disposisi-melenyap juga dapat membuat $\mathrm{AK}^{\mathrm{b}}$ keliru. $\mathrm{AK}^{\mathrm{b}}$ menyatakan bahwa dari fakta bahwa $S x$ menghasilkan $M x$, kita dapat menyimpulkan adanya disposisi $\mathrm{D}_{(\mathrm{S}, \mathrm{M})} x$. Teknik yang digunakan dalam analisis kondisional jenis ini adalah $a b d u k s i$, yakni menarik kesimpulan tentang sesuatu yang tidak teramati berdasarkan fenomena teramati yang dianggap sebagai efek-efeknya. Masih mengikuti ilustrasi dari Bird, andaikan sebuah gelas yang tidak kita ketahui terbuat dari apa tetapi sebenarnya (tanpa kita ketahui) tidak mempunyai disposisi "rapuh." Ketika gelas ini dipukul, andaikan suhunya tiba-tiba menurun drastis sehingga terjadi adesi molekuler secara ekstrem dalam gelas (muncullah disposisi "rapuh") dan

46 Alexander Bird, Nature's Metaphysics, p. 26. 
karenanya gelas malang itu pecah. Jadi, Sx menghasilkan Mx (gelas yang dipukul menghasilkan gelas yang pecah). Akan tetapi, keliru jika kita menyimpulkan bahwa pada waktu kita memukulnya gelas itu memiliki disposisi $\mathrm{D}_{(\mathrm{S}, \mathrm{M})} x$, persis karena $\mathrm{D}_{(\mathrm{S}, \mathrm{M})} x$ baru muncul setelah kita memukulnya (karena intervensi disposisi "adesi molekuler"). Dengan kata lain, (Sx $\square \rightarrow$ $\mathrm{M} x) \rightarrow \mathrm{D}_{(\mathrm{S}, \mathrm{M})} x$ keliru.

Sebagaimana disebut Bird, David Lewis mengajukan koreksi terhadap AK untuk menjawab kesulitan yang diakibatkan oleh pengaruh disposisimelenyap. Koreksi Lewis menambahkan satu sifat baru yang menangkal pengaruh disposisi-melenyap yang ada sampai manifestasi $\mathrm{M}$ terwujud sebut saja "kontra-disposisi-melenyap" - demikian rupa sehingga stimulus $\mathrm{S}$ dan kontra-disposisi-melenyap itu bersama-sama menghasilkan manifestasi M. ${ }^{47}$ Apabila kontra-disposisi yang ada sejak $x$ dikenai $\mathrm{S}$ (katakanlah pada waktu $t$ ) sampai waktu Mx mengemuka (katakanlah $t^{\prime}$ ) tersebut dinotasikan dengan "BxDt," maka "Revisi Analisis Kondisional" yang diberikan Lewis dapat dirumuskan sebagai berikut:

$(\mathrm{RAK}) \quad \mathrm{D}_{(\mathrm{S}, \mathrm{M})} x \leftrightarrow[(\mathrm{S} x \& \mathrm{~B} x \Delta t) \square \rightarrow \mathrm{M} x]$

Artinya, $x$ memiliki disposisi D untuk manifestasi M dalam respon stimulus S jika dan hanya jika terdapat sifat B yang dimiliki $x$ sejak waktu $x$ dikenai $\mathrm{S}$ sampai waktu munculnya $\mathrm{M}$ demikian rupa sehingga seandainya $x$ dikenai $\mathrm{S}$ dan $x$ memiliki B, maka $x$ akan mengalami M. Ilustrasi sederhananya sebagai berikut. Gelas kaca yang kehilangan disposisi "rapuh"-nya (entah karena sihir atau sebab lain) sesaat sesudah terpukul akan tidak pecah. Namun, dengan mengandaikan adanya sifat tertentu $(\mathrm{B} x \mathrm{D} t)$ yang menjamin ketetapan struktur disposisional gelas, gelas itu akan pecah apabila terpukul. Dengan tambahan sifat $\mathrm{B} x \mathrm{D} t$ ini, pengaruh disposisi-melenyap ditepis dari analisis kondisional.

47 "Something $x$ is disposed at time $\boldsymbol{t}$ to give manifestation $M$ to stimulus $S$ iff, for some intrinsic property $B$ that $x$ has at $\boldsymbol{t}$ and for some time $\boldsymbol{t}^{\prime}$, if $\boldsymbol{x}$ were to undergo stimulus $S$ at time $\boldsymbol{t}$ and retain property $B$ until time $\boldsymbol{t}^{\prime}, S$ and $\boldsymbol{x}^{\prime}$ 's having of B would jointly be an $\boldsymbol{x}$-complete cause of $\boldsymbol{x}^{\prime}$ ' giving response M." Alexander Bird, Nature's Metaphysics, p. 27. 
RAK dapat menghalau pengaruh disposisi-melenyap dari definisi kondisional tentang disposisi. Namun, ada jenis disposisi lain yang tidak dapat diselesaikan dengan RAK. Alexander Bird menyebutnya sebagai "penawar" (antidote). Apabila pengaruh disposisi-melenyap bekerja dengan memodifikasi disposisi (meniadakan $\mathrm{AK}^{\mathrm{a}}$ dan mengadakan $\mathrm{AK}^{\mathrm{b}}$ ), penawar bekerja dengan cara memodifikasi stimulus. Contoh sederhana dari penawar adalah penawar racun. ${ }^{48}$ Andaikan seseorang menelan arsenik yang memiliki disposisi "beracun" (poisonous) sehingga akibat stimulus arsenik dalam tubuh, orang tersebut meninggal. Stimulus tersebut adalah pengikatan sulfihidril dalam enzim tubuh yang membuat metabolisme seluler terhambat. Apa yang dilakukan penawar racun bukanlah menghilangkan disposisi "beracun" dalam arsenik, melainkan memodifikasi kondisi dalam tubuh. Penawar racun arsenik, seperti dimerkaprol, bekerja dengan membuat muatan sulfihidril dalam dirinya diikat oleh arsenik sehingga pengikatan arsenik atas sulfihidrol dalam enzim tubuh berkurang. Akibatnya, arsenik tidak membuat orang itu meninggal. Di sini terlihat bahwa penawar tidak bekerja dengan cara menghilangkan disposisi, melainkan dengan memodifikasi situasi rangsangan (dalam contoh di muka, distribusi sulfihidril dalam tubuh). Jadi, kendati disposisi "beracun" yang dimiliki arsenik tetap ada dari awal hingga akhir, manifestasinya-matinya organisme yang mengkonsumsinya - tidak terwujud. Oleh karena penawar sama sekali tidak mengubah disposisi, maka strategi penambahan kontra-disposisi-melenyap tidak berlaku di sini. Konsekuensinya, RAK keliru.

Sampai saat ini, sebatas yang penulis ketahui, belum ada yang mengajukan revisi atas RAK yang disepakati sebagian besar pihak dan dianggap dapat menjawab problem disposisi penawar di muka. ${ }^{49}$ Alexander Bird sendiri memilih untuk memberikan solusi umum dengan rumusan

48 Mengenai penjelasan detail dan hampir teknis terhadap ilustrasi berikut, lih. Alexander Bird, Nature's Metaphysics, pp. 27-28 (khususnya catatan kaki nomor 25).

49 Anthony Everett memberikan survei atas beberapa alternatif yang telah diajukan dalam literatur dan mengaitkannya dengan ketakmemadaian posisi dualisme disposisional dalam menjawab pengaruh disposisi-melenyap dan penawar. Lih. Anthony Everett, “Intrinsic Finks, Masks, and Mimics," Erkenntnis 71 (2009): 196-292. 
fungsi $\mathrm{F}_{(\mathrm{S}, \mathrm{M})} x$ yang dimengerti sebagai "himpunan sifat-sifat dari $x$ yang menjamin tiadanya halangan terhadap $S$ untuk mewujudkan M."50 "Revisi Fungsional atas Analisis Kondisional" ia rumuskan sebagai berikut:

$(\mathrm{RFAK}) \quad \mathrm{D}_{(\mathrm{S}, \mathrm{M})} x \leftrightarrow\left[\left(\mathrm{S} x \& \mathrm{~F}_{(\mathrm{S}, \mathrm{M})} x\right) \square \rightarrow \mathrm{M} x\right]$

Fungsi $\mathrm{F}_{(\mathrm{S}, \mathrm{M})} x$ ini mencakup totalitas kontra-disposisi terhadap disposisimelenyap dan penawar. Melalui revisi fungsional ini, disposisi dapat didefinisikan sebagai sesuatu yang akan teraktualisasi apabila $\mathrm{F}_{(\mathrm{S}, \mathrm{M})} x$ terpenuhi. Dengan demikian, definisi disposisi dari posisi disposisionalisme - baik ekstrem maupun moderat-dapat dirumuskan sebagai berikut:

$\mathbf{D}_{3}$ : pada waktu $w$, objek $x$ memiliki daya untuk $f$ jika dan hanya jika terdapat stimulus $s$ dan himpunan sifat $x$ yang menjamin tiadanya halangan atas $s$ untuk mewujudkan $f$ pada $w$ demikian rupa sehingga $f$ akan terwujud pada $w$.

Dengan rumusan seperti itulah disposisionalisme membangun konsepnya tentang hukum alam. Model hukum seperti apakah yang dapat dibangun dari definisi disposisi ini?

Model hukum yang dapat diwujudkan berdasarkan $\mathbf{D}_{3}$ adalah hukum yang bertopang pada klausa ceteris paribus; artinya, berlaku sejauh mengasumsikan faktor-faktor lain konstan. Bird merumuskan "Hukum Disposisional" sebagai berikut: ${ }^{51}$

$(\mathrm{HD})(\nabla x)\{$ ceteris paribus $[(\mathrm{D} x \& \mathrm{~S} x) \rightarrow \mathrm{M} x]\}$

Dengan model ini, disposisionalisme menjamin keniscayaan hukum alam. Di manapun dan untuk setiap $x$, apabila terdapat disposisi $\mathrm{D}$, stimulus $\mathrm{S}$ dan faktor-faktor lain konstan, maka manifestasi $\mathrm{M}$ akan mengemuka. Kita ingat bahwa menurut kategorialis seperti Armstrong, disposisi benda ditentukan oleh hukum alam yang merupakan turunan dari sifat kategoris yang dapat berubah. Oleh karena hukum alam bersifat kontinjen, maka disposisi benda juga bersifat kontinjen. Menurut disposisionalis, sebaliknya,

50 Lih. Alexander Bird, Nature's Metaphysics, pp. 36-37.

51 Alexander Bird, Nature's Metaphysics, p. 60. 
hukum alam ditentukan oleh disposisi benda dan karena kepemilikan disposisi benda bersifat niscaya, maka hukum alam juga bersifat niscaya. Bird dan Mumford, sebagai pan-disposisionalis, menambahkan bahwa oleh karena hakikat esensial disposisi bersifat relasional, adanya satu disposisi meniscayakan adanya semua disposisi yang berelasi dengannya, baik secara langsung maupun tidak, sehingga relasi antardisposisi itu tidak mungkin kontinjen; karenanya, hukum alam pasti berstatus niscaya. ${ }^{52}$

\section{PENUTUP}

Melalui pemaparan ini kita telah menyaksikan mengapa aktualisme ditinggalkan. Di satu sisi, aktualisme dapat memberikan penjelasan yang ekonomis tentang disposisi, yakni dengan membatasi pembicaraan tentang disposisi sejauh aktualisasinya terberikan. Di sisi lain, aktualisme tidak dapat menerangkan perubahan secara memadai, tidak pula berhasil menjelaskan perbedaan antara disposisi yang tidak teraktualisasi dan ketiadaan disposisi. Konsekuensinya, aktualisme tidak bisa memberikan pendasaran ontologis yang kokoh bagi dakuan tentang hukum alam kecuali dengan argumen keajegan urut-urutan peristiwa aktual. Sebagai alternatif terhadap aktualisme, kita telah memperlihatkan bagaimana kategorialisme dan disposisionalisme mencoba memberikan jawaban atas disposisi yang tidak teraktualisasi dalam kaitannya dengan modalitas hukum alam.

Kategorialisme mereduksi sifat disposisional pada sifat kategoris dan dengan itu cenderung terjatuh ke aktualisme. Apabila sifat disposisional direduksi pada himpunan sifat kategoris, maka keberadaan disposisi mengandaikan aktualitas sifat-sifat kategoris. Konsekuensi selanjutnya,

52 "[T] he laws spring from within the properties themselves. The essential nature of a property is given by its relations with other properties. It wouldn't be that property unless it engaged in those relations. Consequently those relations cannot fail to hold (except by the absence of properties altogether, if that is possible). The laws of nature are thus metaphysically necessary." Alexander Bird, Nature's Metaphysics, p. 2. "Properties come in a holistic package. If the identity of G is in part determined by its causal power to $F$, then unless there is property $F$, there is no property $G$. At best, there might be a property similar to $G$ but if the relation to $F$ is absent then this is not exactly G. Therefore, a world is not possible that contains G but not F." Stephen Mumford, "Powers, dispositions, properties or a causal realist manifesto," p. 148. 
hukum alam menjadi perkara kontinjen yang tergantung pada keberadaan sifat-sifat kategoris di dunia aktual dan tidak mesti ada di dunia-dunia lain yang mungkin. Disposisionalisme menunjukkan ketidaktereduksian sifat disposisional pada sifat kategoris dan menjadikan sifat disposisional sebagai basis penjamin keniscayaan hukum alam. Untuk itu, para disposisionalis berupaya merumuskan definisi tentang disposisi yang mengizinkan keberadaan disposisi yang tidak teraktualisasi. Melalui pemeriksaan atas kasus pengaruh disposisi-melenyap dan penawar, disposisionalis seperti Alexander Bird menunjukkan bahwa aktualisasi disposisi bersifat niscaya sejauh ada sifat-sifat yang menghalangi munculnya intervensi disposisi-melenyap dan penawar, entah melalui modifikasi atas disposisi ataupun stimulus. Keniscayaan disposisional inilah yang dijadikan basis untuk menjamin keniscayaan hukum alam, yakni hukum alam yang dirumuskan dengan bantuan klausa ceteris paribus.

Sungguhkah disposisionalisme berhasil melaksanakan apa yang dijanjikannya, yakni menjamin ketaktereduksian sifat disposisional sekaligus keniscayaan hukum alam? Di sini penulis mempersoalkan realisasi janji tersebut. Penulis berpendapat bahwa definisi final atas disposisi $\left(\mathbf{D}_{3}\right)$ menyimpan permasalahan yang akan berdampak pada rapuhnya klaim disposisionalis bahwa hukum alam bersifat niscaya.

Seperti telah kita lihat dalam RFAK yang menjadi basis $\mathbf{D}_{3^{\prime}}$ Bird menggunakan fungsi $\mathrm{F}_{(\mathrm{S}, \mathrm{M})} x$ untuk menjamin tidak berlakunya pengaruh disposisi-melenyap dan penawar. Menurut penulis, dengan memasukkan fungsi tersebut, Bird terjatuh ke dalam salah satu varian aktualisme, kendati dalam bentuknya yang lebih lemah ketimbang Armstrong. Alasannya berkenaan dengan implikasi modal dari fungsi tersebut. Dengan memasukkan $\mathrm{F}_{(\mathrm{S}, \mathrm{M})} x$ ke dalam definisinya tentang disposisi, Bird mengeluarkan dunia-dunia yang mungkin di mana $\mathrm{F}_{(\mathrm{S}, \mathrm{M})} x$ tidak berlaku, yakni duniadunia yang mungkin di mana terdapat pengaruh disposisi-melenyap dan penawar. Hal ini bermasalah sejauh para disposisionalis, tidak seperti Armstrong, menggunakan kriteria ekstensional untuk mengevaluasi keniscayaan: "F adalah G" niscaya jika dan hanya jika di seluruh dunia 
yang mungkin di mana $\mathrm{F}$ dan $\mathrm{G}$ ada, $\mathrm{F}$ adalah $\mathrm{G} .{ }^{53}$ Semestinya, apabila konsisten dengan kriteria ini, kaum disposisionalis tidak bisa tidak menyimpulkan "Tesis Keniscayaan Disposisional Kuat" berikut:

(TKDK) $\mathrm{D}_{(\mathrm{S}, \mathrm{M})} x \leftrightarrow(\mathrm{S} x \square \rightarrow \mathrm{M} x)$ niscaya jika dan hanya jika di seluruh dunia yang mungkin di mana $\mathrm{D} x$ dan $\mathrm{S} x$ ada, $\mathrm{M} x$ tidak mungkin tidak ada dan di seluruh dunia yang mungkin di mana $\mathrm{S} x$ dan $\mathrm{M} x$ ada, $\mathrm{D}_{(\mathrm{S}, \mathrm{M})} x$ tidak mungkin tidak ada

Alih-alih mengakui TKDK, Bird malah menyimpulkan apa yang dapat kita sebut sebagai “Tesis Keniscayaan Disposisional Lemah:"

(TKDL) $\mathrm{D}_{(\mathrm{S}, \mathrm{M})} x \leftrightarrow(S x \square \rightarrow \mathrm{M} x)$ niscaya jika dan hanya jika di seluruh dunia yang mungkin di mana $\mathrm{D} x$ ada, $\mathrm{S} x$ ada dan $\mathrm{F}_{(\mathrm{S}, \mathrm{M})} x$ berlaku, $\mathrm{M} x$ tidak mungkin tidak ada dan di seluruh dunia yang mungkin di mana $\mathrm{S} x$ ada, $\mathrm{M} x$ ada dan $\mathrm{F}_{(\mathrm{S}, \mathrm{M})} x$ berlaku, $\mathrm{D}_{(\mathrm{S}, \mathrm{M})} x$ tidak mungkin tidak ada.

53 Brian Ellis, misalnya, mengatakan: "While many philosophers may be sympathetic to the idea that the laws of nature are in some sense necessary, and immanent in the world, they are likely to balk at the claim that they are metaphysically necessary. This seems far too strong, for it implies that the laws are true in all possible worlds, just as formal-logical and analytic propositions are. But how can an essentialist possibly be in a position to assert such a thing? They must say, for example, that it is metaphysically necessary that every causal process is intrinsically conservative of energy, and other universally conserved quantities. [...] If a process were not conservative of these quantities, they must say, then it would not be a process of akind that could occur in our world, or in any other world of the same natural kind as ours. [...] There is no serious objection, therefore, to accepting the strong view that the laws of nature are all metaphysically necessary. The more specific laws of nature, the causal and structural laws, which depend on the causal powers and structures of the more specific kinds of things existing in the world, are undoubtedly metaphysically necessary." Brian Ellis, The Philosophy of Nature: A Guide to the New Essentialism (Chesham: Acumen, 2002), pp. 121-122. Bdk. dengan Bird: "An advantage of dispositional monism (and of some version of the mixed view) is that is provides the foundation for an account of the laws of nature: The laws of nature are consequences of the existence of potencies. But since potencies have the same powers in all possible worlds where they exist, [consequently]: The laws of nature are necessary. Dispositional essentialists tend to take [it] in the sense that there is no world in which there is a counterexample to an actual law of nature, allowing for worlds in which the relevant potencies do not exist. It is worth reflecting that a stronger view is natural if one takes a transcendent, Platonist view of universals. Such a view is not mandatory on my account, but I do regard it as an attractive option for the dispositional essentialist." Alexander Bird, Nature's Metaphysics, p. 205. 
Pengandaian tambahan yang dicetak tebal dalam TKDL itu adalah sumber "kelemahan" model keniscayaan yang diajukan Bird. Mengapa demikian? Mengatakan $\mathrm{D}_{(\mathrm{S}, \mathrm{M})} x \leftrightarrow(\mathrm{S} x \square \rightarrow \mathrm{M} x)$ niscaya sejauh $\mathrm{F}_{(\mathrm{S}, \mathrm{M})} x$ berlaku berarti mengatakan bahwa $\mathrm{D}_{(\mathrm{S}, \mathrm{M})} x \leftrightarrow(\mathrm{S} x \square \rightarrow \mathrm{M} x)$ niscaya sejauh basis aktualitasnya dijamin. Persoalannya, disposisionalis mesti menjamin adanya disposisi yang tidak teraktualisasikan dan itu artinya mesti menjamin keberadaan disposisi tanpa keberadaan basis aktualitasnya. Tanpa jaminan itu, kaum disposisionalis tidak dapat menyatakan bahwa $\mathrm{D}_{(\mathrm{S}, \mathrm{M})} x$ niscaya ada; paling banter mereka hanya dapat menyatakan: $\mathrm{D}_{(\mathrm{S}, \mathrm{M})} x$ niscaya ada sejauh aktual dalam dunia di mana $\mathrm{F}_{(\mathrm{S}, \mathrm{M})} x$ berlaku. Tidakkah ini nyaris sama dengan menyatakan bahwa disposisi D niscaya ada dalam dunia-dunia di mana disposisi tersebut aktual?

Persoalan yang sama juga terdapat dalam HD yang menyatakan bahwa (" $x)\{$ ceteris paribus $[(\mathrm{D} x \& \mathrm{~S} x) \rightarrow \mathrm{M} x]\}$. Apakah hukum yang berlandaskan pada klausa ceteris paribus tersebut tidak berkonflik dengan kriteria keniscayaan yang didefinisikan sebagai sesuatu yang berlaku di seluruh dunia yang mungkin di mana D $x$ dan $S x$ ada? Klausa ceteris paribus di sini adalah bentuk lain dari fungsi $\mathrm{F}_{(\mathrm{S}, \mathrm{M})} x$. Jadi, klausa tersebut mengesampingkan beberapa sifat $x$ di luar D $x$ dan $\mathrm{S} x$. Artinya, apabila HD adalah hukum alam, maka statusnya tidak bisa niscaya dalam pengertian mereka. Paling banter kita hanya dapat berkata bahwa hukum alam itu nyaris niscaya, yakni berlaku di dunia-dunia di mana klausa ceteris paribus itu bekerja. Dapat disimpulkan bahwa, setidaknya dalam kerangka disposisionalis yang ada sampai saat ini, tesis keniscayaan hukum alam secara ekstensional tidak dapat dijamin sebelum ketaktereduksian disposisi pada sifat kategoris dan aktualisasinya-atau keberadaan disposisi yang tidak teraktualisasi-dijamin. ${ }^{54}$

54 Analisis kondisional atas disposisi akan membawa kita pada persoalan-persoalan di muka. Adakah pendekatan lain yang dapat menjamin keberadaan disposisi yang tidak teraktualisasi dan dengan itu menjamin pula keniscayaan hukum alam? Molnar, misalnya menempuh jalan lain untuk membicarakan disposisi yang tidak ter-aktualisasi. Berangkat dari ciri relasional disposisi, ia menyimpulkan bahwa setiap disposisi merupakan disposisi untuk sesuatu, bahwa keterarahan merupakan kekhasan disposisi. Dengan itu, Molnar mau menunjukkan bahwa disposisi tidak lain adalah sejenis intensionalitas fisik. Sebagaimana intensionalitas mental mengakui adanya objek intensional yang tidak ada secara aktual (kuda sembrani, misalnya), demikian pula inten- 
Kendati demikian, jaminan "keniscayaan" hukum alam yang diberikan kaum disposisionalis tetaplah lebih kuat ketimbang alternatif yang disuguhkan kategorialisme dan aktualisme. Ilmu pengetahuan, setidaknya dalam pengertian realisnya, memerlukan teori yang masuk akal tentang disposisi dan keniscayaan. Apabila status ontologis disposisi diposisikan pada level derivatif (seperti dalam kategorialisme) atau bahkan diciutkan sepenuhnya pada manifestasi empiriknya (seperti dalam aktualisme), maka dakuan ilmu-ilmu atas keberadaan objek-objek - yang dilandasi oleh penjelasan kausal berdasarkan konsep disposisi - tidak lebih adalah dakuan fenomenal dan akibatnya, realitas yang dibicarakan oleh ilmu-ilmu menjadi kehilangan sisi objektifnya. Apabila hukum alam hanya berstatus kontinjen (terikat pada variabel aktual dunia tertentu), maka pertanyaan tentang mengapa kenyataan berlaku secara tertentu kemudian diciutkan menjadi pertanyaan tentang bagaimana dunia terberikan secara tertentu pada kesadaran: pertanyaan soal hukum alam diciutkan menjadi pertanyaan soal pengorganisasian fenomena. Karena itu, menurut penulis, upaya lebih lanjut untuk memperbaiki pandangan disposisionalis tentang ketidakaktualan disposisi dan modalitas hukum alam akan memberikan sumbangan bagi peletakan landasan realis yang kokoh bagi ilmu pengetahuan.

sionalitas fisik. "An intentional property can exist whether its intentional object exists or not. A purely physical object can be soluble without ever dissolving, or fragile without ever breaking." George Molnar, Powers, p. 63. Di sini keberadaan disposisi yang tidak teraktualisasi dijamin, tetapi dengan harga yang tidak murah. Identitas disposisi kemudian didefinisikan berdasarkan relasinya dengan sesuatu yang tidak ada. Pendekatan semacam ini, seperti diduga Armstrong, berisiko membawa kita ke sejenis Meinongianisme. Bdk. David Armstrong, A World of States of Affairs, p. 79. Meinongianisme adalah pandangan yang berasal dari Alexius Meinong bahwa objek-objek yang tidak ada (misalnya gunung emas atau persegi yang bulat) sebetulnya "ada." kendati tidak aktual. Bdk. Karel Lambert, "Alexius Meinong" in A Companion to Metaphysics, ed. Jaegwon Kim, et al., p. 407. Persoalannya, Meinongianisme masih kontroversial hingga kini sebab, apabila posisi ini kita terima, kita tidak hanya diizinkan untuk berbicara tentang dunia-dunia yang mungkin (possible worlds), tetapi juga tentang dunia-dunia yang tidak mungkin (impossible worlds) - dunia-dunia di mana, misalnya, $\mathrm{P}$ adalah sekaligus juga non-P. Tentu ini merupakan beban yang berat - baik dalam arti metafisis maupun logis - bagi kaum disposisionalis (yang tanpa Meinongianisme pun sudah kesulitan menjustifikasi keberadaan disposisi yang tidak teraktualisasi). 


\section{DAFTAR RUJUKAN}

Aristoteles. "Metaphysics." Trans. W.D. Ross. In The Complete Works of Aristotle Volume II, ed. Jonathan Barnes. New Jersey: Princeton University Press, 1995, pp. 1552-1728.

Armstrong, D.M. Universals \& Scientific Realism Volume II: A Theory of Universals. Cambridge: Cambridge University Press, 1978.

. A World of States of Affairs. Cambridge: Cambridge University Press, 1997.

"Place's and Armstrong's Views Compared and Contrasted." In Dispositions: A Debate, ed. Tim Crane. London: Routledge, 1996, pp. 33-48

Bhaskar, Roy. A Realist Theory of Science. Leeds: Leeds Books, 1975.

Bird, Alexander. Nature's Metaphysics: Laws and Properties. Oxford: Clarendon Press, 2007.

Chalmers, David. "Supervenience." In Emergence: Contemporary Readings in Philosophy and Science, eds. Mark A Bedau and Paul Humphreys, Massachusetts: The MIT Press, 2008, pp. 411-425.

Deutsch, Harry. "Extension/intension." In A Companion to Metaphysics, eds. Jaegwon Kim, et al., West Sussex: Wiley-Blackwell, 2009, pp. 254-256.

Ellis, Brian. The Philosophy of Nature: A Guide to the New Essentialism. Chesham: Acumen, 2002.

Scientific Essentialism. Cambridge: Cambridge University Press, 2001.

Everett, Anthony. "Intrinsic Finks, Masks, and Mimics." Erkenntnis 71 (2009): 191-203.

Galilei, Galileo. “The Assayer." In The Essential Galileo, ed. Maurice A. Finocchiaro. Indianapolis: Hackett Publishing Company, 2008, pp. 179-189.

Harré, Rom dan Edward H. Madden, Causal Powers: A Theory of Natural Necessity. Oxford: Basil Blackwell, 1975.

Harré, Rom. The Philosophies of Science: An Introductory Survey. Oxford: Oxford University Press, 1985.

Heil, John. Philosophy of Mind: A Contemporary Introduction. London: Routledge, 2004. 
Hume, David. An Enquiry Concerning Human Understanding, ed. Peter Millican. Oxford: Oxford University Press, 2007.

The Philosophical Works Volume II: A Treatise of Human Nature, Parts II and III. Edinburgh: Adam Black and William Tait, 1826.

Kripke, Saul. Naming and Necessity. Cambridge, MA: Harvard University Press, 2001.

Lambert, Karel. "Alexius Meinong." In A Companion to Metaphysics, eds. Jaegwon Kim, et al., West Sussex: Wiley-Blackwell, 2009, pp. 406409.

Lewis, David. On The Plurality of Worlds. Oxford: Basil Blackwell, 1986.

Locke, John. The Works of John Locke Volume I: An Essay Concerning Human Understanding, Part I. London: Rivington, 1824.

Lowe, E.J. The Four-Category Ontology: A Metaphysical Foundation for Natural Science. Oxford: Clarendon Press, 2006.

McLaughlin, Brian P. "Emergence and Supervenience." In Emergence: Contemporary Readings in Philosophy and Science, eds. Bedau and Paul Humphreys, Massachusetts: The MIT Press, 2008, pp. 81-97.

. "Varieties of Supervenience." In Supervenience: New Essays, eds. Elias E. Savellos and Ümit D. Yalçin, Cambridge: Cambridge University Press, 1995, pp. 16-59.

Molnar, George. Powers: A Study in Metaphysics, ed. Stephen Mumford. Oxford: Oxford University Press, 2006.

Mumford, Stephen. "Passing Powers Around." The Monist 92/1 (Januari, 2009): 94-111.

"Powers, dispositions, properties or a causal realist manifesto." In Revitalizing Causality: Realism about Causality in Philosophy and Social Science, ed. Ruth Groff, London: Routledge, 2008, pp. 139151.

Newton, Isaac. "De Gravitatione." In Philosophical Writings, ed. Andrew Janiak. Cambridge: Cambridge University Press, 2004, pp. 12-39.

."Philosophiae Naturalis Principia Mathematica." In Philosophical Writings, ed. Andrew Janiak. Cambridge: Cambridge University Press, 2004, pp. 40-93.

Shoemaker, Sydney. Physical Realization. Oxford: Oxford University Press, 2007. 